\title{
Scaling the effects of ocean acidification on coral growth and coral-coral competition on coral community recovery
}

\author{
Nicolas R Evensen ${ }^{\text {Corresp., }, 2,3}$, Yves-Marie Bozec $^{3}$, Peter J Edmunds $^{2}$, Peter J Mumby ${ }^{3}$ \\ 1 Department of Biological Sciences, Old Dominion University, Norfolk, Virginia, United States \\ 2 Department of Biology, California State University, Northridge, Northridge, California, United States \\ 3 Marine Spatial Ecology Lab, ARC Centre of Excellence for Coral Reef Studies and School of Biological Sciences, University of Queensland, St Lucia, \\ Queensland, Australia \\ Corresponding Author: Nicolas R Evensen \\ Email address: nicolas.r.evensen@gmail.com
}

Ocean acidification (OA) is negatively affecting calcification in a wide variety of marine organisms. These effects are acute for many tropical scleractinian corals under short-term experimental conditions, but it is unclear how these effects interact with ecological processes, such as competition for space, to impact coral communities over multiple years. This study sought to test the use of individual-based models (IBMs) as a tool to scale up the effects of OA recorded in short-term studies to community-scale impacts, combining data from field surveys and mesocosm experiments to parameterize an IBM of coral community recovery on the fore reef of Mo'orea, French Polynesia. Focusing on the dominant coral genera from the fore reef, Pocillopora, Acropora, Montipora, and Porites, model efficacy first was evaluated through the comparison of simulated and empirical dynamics from 2010-2016, when the reef was recovering from sequential acute disturbances (a crown-of-thorns seastar outbreak followed by a cyclone) that reduced coral cover to $\sim 0 \%$ by 2010 . The model then was used to evaluate how the effects of OA (1100-1200 $\mu$ atm $\mathrm{pCO}_{2}$ ) on coral growth and competition among corals affected recovery rates (as assessed by changes in \% cover $\mathrm{y}^{-1}$ ) of each coral population between 2010-2016. The model indicated that recovery rates for the fore reef community was halved by OA over 7 years, with cover increasing at $11 \% \mathrm{y}^{-1}$ under ambient conditions and $4.8 \% \mathrm{y}^{-1}$ under OA conditions. However, when OA was implemented to affect coral growth and not competition among corals, coral community recovery increased to $7.2 \% \mathrm{y}^{-1}$, highlighting mechanisms other than growth suppression (i.e., competition), through which OA can impact recovery. Our study reveals the potential for IBMs to assess the impacts of OA on coral communities at temporal and spatial scales beyond the capabilities of experimental studies, but this potential will not be realized unless empirical analyses 
address a wider variety of response variables representing ecological, physiological, and functional domains. 
1 Scaling the effects of ocean acidification on coral growth and coral-coral

\section{2 competition on coral community recovery}

3 Nicolas R. Evensen ${ }^{1,2,3^{*}}$, Yves-Marie Bozec ${ }^{1}$, Peter J. Edmunds ${ }^{2}$, Peter J. Mumby ${ }^{1}$

4

$5 \quad{ }^{1}$ Marine Spatial Ecology Lab, ARC Centre of Excellence for Coral Reef Studies and School of

6 Biological Sciences, The University of Queensland, St Lucia, Queensland, Australia

$7 \quad 2$ Department of Biology, California State University, Northridge, CA, USA

$8 \quad{ }^{3}$ Department of Biological Sciences, Old Dominion University, Norfolk, VA, USA

$10 *$ *orresponding Author:

11 Email address: nicolas.r.evensen@gmail.com 


\section{ABSTRACT}

13 Ocean acidification (OA) is negatively affecting calcification in a wide variety of marine

14 organisms. These effects are acute for many tropical scleractinian corals under short-term

15 experimental conditions, but it is unclear how these effects interact with ecological processes,

16 such as competition for space, to impact coral communities over multiple years. This study

17 sought to test the use of individual-based models (IBMs) as a tool to scale up the effects of OA

18 recorded in short-term studies to community-scale impacts, combining data from field surveys

19 and mesocosm experiments to parameterize an IBM of coral community recovery on the fore

20 reef of Mo'orea, French Polynesia. Focusing on the dominant coral genera from the fore reef,

21 Pocillopora, Acropora, Montipora, and Porites, model efficacy first was evaluated through the

22 comparison of simulated and empirical dynamics from 2010-2016, when the reef was recovering

23 from sequential acute disturbances (a crown-of-thorns seastar outbreak followed by a cyclone)

24 that reduced coral cover to $\sim 0 \%$ by 2010 . The model then was used to evaluate how the effects of OA (1100-1200 $\left.\mu \mathrm{atm} \mathrm{pCO}_{2}\right)$ on coral growth and competition among corals affected recovery rates (as assessed by changes in $\%$ cover $y^{-1}$ ) of each coral population between $2010-2016$. The model indicated that recovery rates for the fore reef community was halved by OA over 7 years, with cover increasing at $11 \% \mathrm{y}^{-1}$ under ambient conditions and $4.8 \% \mathrm{y}^{-1}$ under OA conditions. However, when OA was implemented to affect coral growth and not competition among corals, coral community recovery increased to $7.2 \% \mathrm{y}^{-1}$, highlighting mechanisms other than growth

31 suppression (i.e., competition), through which OA can impact recovery. Our study reveals the

32 potential for IBMs to assess the impacts of OA on coral communities at temporal and spatial

33 scales beyond the capabilities of experimental studies, but this potential will not be realized 
34 unless empirical analyses address a wider variety of response variables representing ecological,

35 physiological, and functional domains.

36 INTRODUCTION

37 Evaluation of the effects of ocean acidification (OA) on marine organisms (Kroeker et al., 2010;

38 Wittmann \& Pörtner, 2013) supports the general conclusion that biogenic calcification will be

39 depressed by rising seawater $\mathrm{pCO}_{2}$ (Chan \& Connolly, 2013; Kornder et al., 2018; Kroeker et al.,

40 2013). For scleractinian corals, elevating $\mathrm{pCO}_{2}$ above current atmospheric levels (i.e., $\sim 400$

$41 \mu \mathrm{atm})$ mostly results in decreased calcification (Chan \& Connolly, 2013; Comeau et al., 2014a),

42 although species differ in the sensitivity of net calcification to high $\mathrm{pCO}_{2}$ (Comeau et al., 2014b;

43 Edmunds et al., 2012). Additionally, OA can reduce coral recruitment (Albright \& Langdon,

44 2011; Doropoulos et al., 2012; Fabricius et al., 2017), although it is thought to have little effect

45 on the survival of juvenile or adult corals (Kroeker et al., 2013).

46 Beyond affecting vital rates (like recruitment), elevated $\mathrm{pCO}_{2}$ also has the potential to

47 alter the synecology of coral reefs, for example, by altering competitive dynamics between corals

48 and algae (Diaz-Pulido et al., 2011), as well as among corals (Evensen \& Edmunds, 2016;

49 Horwitz, Hoogenboom \& Fine, 2017). It is challenging, however, to predict how the effects of

50 OA on ecological and demographic processes will scale up to affect coral community dynamics

51 (Albright \& Langdon, 2011; Edmunds et al., 2016a). This challenge is intensified as the

52 prediction extends further in to the future, because predictions over decades or centuries requires

53 the effects of OA to be considered against a backdrop of chronic and acute disturbances, such as

54 major storms and ocean warming (Hughes et al., 2017). The most ambitious predictions also

55 require consideration of the potential for acclimatization or adaptation (Schoepf et al., 2017;

56 Kurihara et al., 2020). 
Field and mesocosm studies of the response of coral communities to OA face significant

58 challenges of sustaining experiments for ecologically relevant durations (i.e., months to a year),

59 and procuring sufficient replicate organisms within the constraints of permitting and ethics.

60 Modelling provides a tractable alternative to empirical studies, with individual-based models

61 (IBMs) supporting accurate simulations of the spatial dynamics of coral colonies within reef

62 communities (Mumby, Hastings \& Edwards, 2007; Sandin \& McNamara, 2012). IBMs can also

63 support decadal-scale projections of coral population structure when they include empirical

64 determinations of vital rates (e.g., recruitment and growth), and mechanistic understanding of

65 ecological processes, such as competitive interactions. Despite the potential of IBMs to evaluate

66 the response of coral communities to contrasting disturbance regimes (Muko et al., 2014; Ortiz et

67 al., 2014), they have not been widely applied to study the effects of OA on coral reefs. To date,

68 the most comprehensive modelling approach forecasting the impacts of OA on corals included

69 one coral (Acropora) and one macroalgal (Lobophora) genus, to demonstrate that increased

70 intensity of competition between corals and algae can interact with OA to lower coral

71 calcification (Anthony et al., 2011). In complex coral reef communities including a greater

72 number of coral and algal taxa, taxonomically variable responses to OA, and a wider diversity of

73 perturbed ecological interactions, are likely to result in the detection of strong, community-wide

74 effects. Consideration of more complex ecological situations will be necessary to improve the

75 ecological relevance and accuracy of models seeking to determine how reef communities will

76 change upon long-term exposure to OA.

77 The present study sought to expand on the use of modelling approaches to scale up the

78 impacts of elevated $\mathrm{pCO}_{2}$ across larger spatio-temporal scales, using the IBM approach of

79 Mumby et al. (2007) to evaluate how coral community dynamics will change in a future strongly 
80 affected by OA. In this application, the effects of high $\mathrm{pCO}_{2}$ on coral growth were species

81 specific, and coral-coral competition was implemented to modulate community dynamics in a

82 manner that differed among $\mathrm{pCO}_{2}$ regimes. The model was implemented for the coral

83 community on the fore reef of Mo'orea, French Polynesia (Fig. S1), and it utilized two domains

84 of empirical data. First, results from manipulative experiments were utilized to quantify the

85 effects of elevated $\mathrm{pCO}_{2}$ on the growth (linear extension) and capacity for competition among

86 the four common coral genera (Pocillopora, Acropora, Montipora, and Porites) found on the

87 fore reef (10-m depth) of Mo'orea (Evensen, Edmunds \& Sakai, 2015; Evensen \& Edmunds,

88 2016). Second, vital rates for each genus were obtained from an ecological time-series of coral

89 community structure at 10-m depth on fore reef of Mo'orea (Edmunds, 2018a; Holbrook et al.,

90 2018). This time series extended from 2005 to present, but only results from 2010-2016 were

91 employed in the present analysis with the rationale that this period spans a remarkable time in the

92 history of these reefs, commencing with virtually no coral as a result of COTs and a cyclone

93 (Kayal et al., 2012), and ending with 66\% coral cover in 2016 (Edmunds, 2018a). The model

94 was used to determine how the effects of OA on coral growth and competition affect coral

95 populations and the rate of coral community recovery following acute disturbances.

97 Methods

98 Model overview

99 An individual-based, spatially explicit model of coral population structure, developed by Mumby

100 and colleagues (Bozec et al., 2016; Mumby et al., 2007; Ortiz et al., 2014), was used to project

101 coral community cover in Mo'orea. The model was developed for Caribbean reefs (Mumby,

102 Hastings \& Edwards, 2007) and later extended to Indo-Pacific reefs (Ortiz et al., 2014). Here, the 
103 model is adapted to the fore reef of Mo'orea by parameterization with empirical data from this

104 location that describe vital rates for the common coral genera, as well as the outcomes on colony

105 growth of coral-coral competition under OA (Evensen \& Edmunds, 2016). Permits for fieldwork

106 were issued by the Haut-commissariat de la République en Polynésie Française (DRRT)

107 (Protocole d'Accueil 2010-2011, 2011-2012, 2012-2013, 2013-2014, 2014-2015, 2015-2016

108 to PJE).

109 The model simulated the fate of coral colonies on a square lattice of 400 cells, with each

110 cell representing $1 \mathrm{~m}^{2}$ of reef substratum. Cells in the model could be occupied by multiple coral

111 colonies of different genera, with each colony quantified by its cross-sectional (circular) planar

112 area. The model advanced in 6-month increments, with colony size (in $\mathrm{cm}^{2}$ ) and density updated

113 every time step. Coral colonies increased in size based on: (1) genus-specific rates of linear

114 (radial) growth (Table S1), (2) competition with con- and hetero- specifics (Table 1), and (3) the

115 sensitivity of coral growth (i.e., linear extension) to elevated $\mathrm{pCO}_{2}$ (Table S2). The effects of

116 competition and OA on colony growth rates are detailed below.

118 Modelling competition between coral colonies

119 Ecological realism was added to the model by (1) addressing the competitive interactions that

120 occur when coral colonies encounter one another while growing and occupying space on the

121 benthos, and (2) evaluating how these interactions might be modified by future environmental

122 conditions. To capture the effects of coral-coral competition, we first determined the extent to

123 which the perimeter of coral colonies encounter (i.e., touch) one another as they spread across

124 the benthos, growing symmetrically as planar circles. This information was extracted from 0.25

$125 \mathrm{~m}^{2}$ photoquadrats recorded annually $\left(\mathrm{n}=\sim 40 \mathrm{y}^{-1}\right)$ at fixed positions along a transect at $10-\mathrm{m}$ 
126 depth at the LTER1 site on the north shore of Mo'orea. The photoquadrats used in the present

127 study came from 2010-2016, which is the period of recovery of the coral community following

128 the outbreak of COTS and a cyclone; these data were proportionately scaled to $1 \mathrm{~m}^{2}$ to match the

129 size of the model cells. In each photoquadrat, the distance among colony centroids and the radius

130 of each colony following 6 months of growth (i.e., the model time step) were measured and used

131 to calculate the length of the perimeter of each colony in contact with another (Fig. 1a-b). For

132 these calculations, colonies of all four genera were assumed to extend linearly in planar view by

$1331.6 \mathrm{~cm}$ every 6 months, which corresponds to the average linear growth rate of all four genera

134 over a 6-month period (Table S1). Full code detailing the calculations can be found in

135 Supplementary Material.

136 Data recorded from the photoquadrats were used to parameterise a model simulating

137 random scenarios of placement of coral colonies varying in size and density within model cells

138 (Fig. 1c). Colony sizes were generated at random following the log-normal distribution of colony

139 sizes observed in the LTER1 photoquadrats from 2010-2016, with colony densities ranging from

1402 to 35 colonies $\mathrm{m}^{-2}$ to match the observed range of colony densities recorded between 2010-

141 2016. This produced a relationship of the rate at which coral colonies engage in competitive

142 encounters with neighbouring colonies (i.e., they contact one another) as coral cover increases.

143 Measurements were recorded within the $1 \mathrm{~m}^{2}$ cells of the model, in which the size of colonies

144 (but not their exact location) was recorded at each time step. The relationship between coral

145 cover and mean percentage of the perimeter of each colony that contact adjacent colonies (i.e.,

146 extent of competitive encounters among corals) was fitted by a linear model after square-root

147 transformation of coral cover (Fig. 1c). The linear relationship between coral cover and

148 competition among corals was integrated into the IBM by generating an average value of contact 
149 between colonies, within the 95\% C.I. of predictions from the linear model, for every grid cell as

150 a function of coral cover.

151 Following quantification of the rate and extent of contact among coral colonies (i.e.,

152 competition) as a function of coral cover, the effect of this contact on linear extension was

153 integrated into the model designed to project coral cover over time. The outcome of coral-coral

154 contact varied as a function of competitor identity (i.e., con- versus hetero- specifics) and the

155 extent of contact (proportion of the colony perimeter) with the competitor. The effect of contact

156 with conspecifics and heterospecifics under ambient and OA conditions were based on results

157 from Evensen \& Edmunds (2016), in which the consequences of competitive encounters between

158 Pocillopora verrucosa and conspecifics and heterospecifics (A. hyacinthus) in Mo'orea were

159 evaluated by the extent to which planar linear extension of $P$. verrucosa was depressed by these

160 encounters under ambient $(411 \mu \mathrm{atm})$ and elevated $\mathrm{pCO}_{2}(1033 \mu \mathrm{atm})$.

161 Evensen \& Edmunds (2016) conducted experiments in which colonies of $P$. verrucosa

162 were surrounded with 2-4 colonies of con- or hetero-specifics in 500-L outdoor flumes (Fig. 2a),

163 with the impact of competition among these colonies inferred from changes in linear growth of

$164 P$. verrucosa after 4 weeks. The dependence of linear extension on percentage contact with

165 competitors under ambient and elevated $\mathrm{pCO}_{2}$ was fitted with either a simple linear model

166 (Equation 1, Table 1) or an exponential decay function (Equation 2, Table 1), depending on the

167 best model fit, as estimated by Akaike information criterion (AIC).

168 Other than the aforementioned data for Pocillopora, data were unavailable to quantify the

169 growth response of Acropora, Porites and Montipora when competing with conspecifics or

170 heterospecifics, although evidence from the Red Sea suggests growth is affected equally by

171 competition for each of these genera (Horwitz, Hoogenboom \& Fine, 2017). Thus, the empirical 
172 relationship between linear growth and percentage contact with conspecifics determined for

173 Pocillopora was assumed to apply to all genera in the present study, although linear extension

174 rates in the absence of competition and the effect of elevated $\mathrm{pCO}_{2}$ remained specific to each

175 genus. In turn, genus-specific responses of corals to heterospecific competition were

176 parameterized by modifying the relationship between linear growth and contact with

177 heterospecifics based on previously reported competitive hierarchies that include the present

178 genera (i.e., Acropora $>$ Pocillopora $>$ Montipora $>$ Porites; based on Dai, 1990; Connell et al.,

179 2004; Evensen, Edmunds \& Sakai, 2015; Horwitz, Hoogenboom \& Fine, 2017). As the

180 relationship between linear growth and contact with heterospecifics was best described by an

181 exponential decay model, genus-specific responses of corals to heterospecific competition were

182 implemented by altering the rates at which linear growth of Pocillopora declined as a function of

183 contact with heterospecifics. Relative to Pocillopora, rates of decline in linear growth as a

184 function of increasing contact with heterospecifics were $44 \%$ slower for Acropora, and $22 \%$ and $18544 \%$ faster for Montipora and Porites, respectively (Table 1).

187 Evaluating model accuracy: simulating coral community recovery after disturbances

188 The model was implemented with the coral cover of each genus recorded at 10-m depth on the

189 north shore of Mo'orea in April 2010, which consisted of 0.2\% cover of Porites following

190 several years of a COTS outbreak and a cyclone in February 2010 (Edmunds 2018a). By 2016,

191 coral cover at the same site had reached $66 \pm 3 \%$, with Acropora, Pocillopora, Porites, and

192 Montipora, contributing $>97 \%$ of the cover. Our model, therefore, focused on: Pocillopora,

193 which in this location includes at least $P$. verrucosa, $P$. meandrina, $P$. eydouxi, P. effuses, and

194 several unnamed haplotypes (Edmunds et al., 2016b; Burgess et al., 2021); Acropora spp. which 
195 includes at least 15 species (Bosserelle et al., 2014); Montipora spp. which includes at least 9

196 species (Bosserelle et al., 2014); and Porites which was evaluated as the functional group

197 “massive Porites" including P. lutea, P. lobata, and P. australiensis (Edmunds, 2018a).

198 Conversely, coral-macroalgal competition was not modelled in the present study as

199 macroalgae has remained at $<5 \%$ cover at 12-m depth on the fore reefs of Mo'orea since 1991

200 (Adjeroud et al., 2018) and thus is not a major competitor for space at this fore reef site. Indeed,

201 the most abundant macroalgae at this site, Asparagopsis taxiformis, did not exceed 5\% cover

202 between 2010 and 2016 in the photoquadrats and steadily decreased in cover as coral cover

203 increased. As such, coral-macroalgal interactions were not common during the recovery of the 204 coral community.

205

206 Each time step in the model (6 months) was informed with quantitative vital rates

207 characterizing the four genera (described below; Tables S1). The accuracy of the population

208 projections was determined by comparing the projected coral cover by year with the empirical

209 data recorded from 2010 to 2016 at 10-m depth at LTER1 on the north shore of Mo'orea

210 (Edmunds, 2018a).

211 Rates of whole and partial colony mortality were estimated from previously published

212 research that employed in situ tracking of Acropora, Pocillopora, and Porites colonies,

213 conducted annually between 2011 and 2013 at LTER1 (Lenihan \& Kayal, 2015; Kayal et al.,

214 2018; Table S1). Rates of whole colony mortality were based on the proportion of colonies that

215 did not survive between sampling times, while rates of partial colony mortality were based on the

216 proportion of colonies that experienced shrinkage between sampling times. Rates of whole and

217 partial mortality for Montipora were based on measurements obtained for Acropora, as 
218 Montipora colonies were not included in the study by Kayal et al. (2018). Linear growth rates for

219 Pocillopora were based on results from Evensen \& Edmunds (2016), and linear extension rates

220 for Acropora, Montipora, and Porites were obtained from published studies (Tables S1). Coral

221 recruitment was measured using settlement tiles immersed for $\sim 6$ months and deployed

222 sequentially from 2009 to 2016 on the North shore of Mo'orea (summarized in Edmunds, 2021).

223 Tiles were immersed from January/February to August/September and from August/September

224 to January/February. Recruitment was recorded by family, with results for Pocilloporidae and

225 Poritidae used to parameterise Pocillopora and Porites, respectively. In turn, recruitment rates of

226 Acroporidae were split equally to parameterise recruitment for Acropora and Montipora, though

227 these rates were later adjusted (detailed below).

228 The efficacy of the IBM was evaluated through a contrast of projected and empirical

229 coral cover, and discrepancies between these values under control conditions (i.e., ambient

$230 \mathrm{pCO}_{2}$ ) were addressed by reviewing the parameter values established for vital rates. As coral

231 recruitment in Mo'orea varied extensively among years (Edmunds, 2021), this vital rate was

232 targeted for adjustment in order to reduce the discrepancy between empirical and projected coral

233 cover. Recruitment rates were adjusted until empirical and projected cover of each genus after 7

234 years differed by $<1 \%$, and the revised recruitment rate then was used in the projections of coral 235 cover under OA conditions.

236

237 Quantifying the impact of $O A$ on coral recovery following acute disturbances

238 The model was used to assess the impact of elevated $\mathrm{pCO}_{2}$ on coral community recovery over 7

239 years following 2010, relative to coral community recovery under ambient conditions. The

240 impacts of OA on coral community recovery were modelled in two steps. The first step

Peer] reviewing PDF | (2021:02:58344:1:1:NEW 12 May 2021) 
241 implemented the effects of elevated $\mathrm{pCO}_{2}$ on linear growth rates of corals in the absence of

242 competition, with growth rates modified based on measurements of linear growth for each genus

243 under elevated $\mathrm{pCO}_{2}$. Based on experiments with Pocillopora and Montipora in Mo'orea, linear

244 growth rates over $28 \mathrm{~d}$ were reduced by $30 \%$ (at $972 \mu$ atm $\mathrm{pCO}_{2}$ ) and $43 \%$ (at $1033 \mu \mathrm{atm} \mathrm{pCO}_{2}$ )

245 relative to ambient conditions (Evensen, Edmunds \& Sakai, 2015; Evensen \& Edmunds, 2016).

246 The linear growth rate of Acropora spp. under OA conditions has not been recorded in Mo'orea

247 and, therefore, the effects were based on a study from Eilat, Israel, in which the linear growth of

248 Acropora was depressed by $37 \%$ under elevated $\mathrm{pCO}_{2}(1795 \mu \mathrm{atm})$ compared to ambient

249 conditions (400 $\mu \mathrm{atm}$; Horwitz, Hoogenboom \& Fine, 2017). Lastly, growth rates of massive

250 Porites were considered to be unaffected by OA compared to ambient simulations in the present

251 analysis, based on a study from Mo'orea in which elevated $\mathrm{pCO}_{2}(804 \mu \mathrm{atm})$ had no effect on

252 calcification rate (mass per area) of massive Porites compared to ambient $\mathrm{pCO}_{2}$ (Edmunds,

253 Brown \& Moriarty, 2012). The second step implemented the effects of coral competition among

254 corals on coral growth rates under elevated $\mathrm{pCO}_{2}$, using the approach described above under

255 Step 1. This two-step approach allowed the model to differentiate between simulating the effects

256 of OA on colony growth alone and simulating the effects of OA on both colony growth and

257 competition among corals. The advantage of this approach is that it supported separate

258 consideration of two mechanisms by which elevated $\mathrm{pCO}_{2}$ can impact coral communities.

259 For all scenarios, 100 simulations were conducted, from which the average coral cover

260 was calculated to assess the impact of OA on coral recovery, relative to ambient $\mathrm{pCO}_{2}$. All

261 model simulations were conducted using MATLAB (v9.1 R2016b; MathWorks, Natick,

262 Massachusetts, USA). Figures were plotted in R using 'ggplot2' (Wickham, 2016) or in Prism

263 (v. 8.0; GraphPad Software, Inc.). 
265 Sensitivity analysis

266 The relative impact of linear growth rates, competition among corals, recruitment, and partial

267 and whole colony mortality on simulations of coral community recovery were assessed through a

268 sensitivity analysis. Parameter sensitivity was evaluated based on the deviation of model

269 projections with the $\pm 20 \%$ change in each parameter after Bozec et al. (2019), relative to the

270 mean coral cover predicted after 7 years under ambient conditions.

271

272 Results

273 Modelling the relationship between coral-coral competition and linear growth

274 For conspecific interactions under ambient $\mathrm{pCO}_{2}$, the effects of competition on linear extension

275 were best described by a linear relationship between growth reduction and percent contact (Fig.

276 2b), and for heterospecific interactions under ambient $\mathrm{pCO}_{2}$, the effects of competition on linear

277 extension were best described by an exponential decay model (Fig. 2c). Under elevated pCO

278 exponential decay models were better fitted to the relationships between linear extension and

279 contact with conspecifics and heterospecifics under elevated $\mathrm{pCO}_{2}$ (Fig. 2d,e).

280

281 Model accuracy

282 Following 7 years of recovery initiated after coral cover was depressed to $0.3 \%$ in 2010 ,

283 simulated coral cover reached $67.1 \%$ by 2016 , a $1 \%$ difference from observed values, $66.1 \%$, in

2842016 (Fig. 3a). Recruitment rates of Pocillopora $\left(4.15\right.$ corals $^{-2}$ ) required a $10 \%$ increase to

285 match observed rates of recovery, with Pocillopora cover reaching 50\% after 7 years, compared

286 to an observed value of $49.8 \%$ (Fig. 3b). In turn, Montipora cover reached $10.2 \%$ after 7 years, 
287 compared to an observed value of $10.1 \%$, following a $142 \%$ increase in modelled recruitment

288 rate $\left(2.42\right.$ corals $\left.\mathrm{m}^{-2}\right)$. Acropora recruitment $\left(0.25\right.$ corals $\left.^{-2}\right)$ was reduced by $50 \%$ in order for

289 simulations to end with $3.2 \%$ cover, compared to the observed cover of $2.8 \%$ after 7 years.

290 Lastly, Porites required the biggest adjustment in empirical recruitment rates in order for

291 empirical and simulated cover of this genus to converge on $\sim 3.5 \%$ after 7 years, with this

292 outcome requiring a six-fold increase in empirical recruitment (3.9 corals $\left.\mathrm{m}^{-2}\right)$.

293

294 Rates of coral recovery under ambient and elevated $\mathrm{pCO}_{2}$

295 When the effects of OA on coral growth were implemented, without the effects of OA on

296 competition, coral cover following 7 years of recovery reached $42.9 \%$, which was $24.2 \%$ less

297 than projections of coral community cover under ambient $\mathrm{pCO}_{2}$. In turn, when the effects of OA

298 on both coral growth and coral-coral competition were implemented in the model, coral cover

299 reached only $28.9 \%$ after 7 years (Fig. 3a), with Pocillopora accounting for $81 \%$ of the total

300 coral cover at the end of the projections (Fig. 3b).

301

302 Sensitivity analysis

303 The sensitivity analysis demonstrated that changes to coral linear growth rates had the strongest

304 effects on model projection, followed by changes to recruitment rates and competition among

305 corals (Fig. 4). $\mathrm{A} \pm 20 \%$ change in linear growth rate caused $-24.4 \%$ declines and $+19.1 \%$

306 increases in projected coral cover over 7 years; $a \pm 20 \%$ change in recruitment led to $-14.6 \%$

307 declines and $+9.2 \%$ increases in projected coral cover over 7 years; and a $\pm 20 \%$ change in

308 competition led to $-9.7 \%$ declines and $+11.8 \%$ increases in projected coral cover. $\mathrm{A} \pm 20 \%$

309 changes to partial and whole colony mortality rate had little effect on the rate at which coral 
310 cover recovered following large-scale mortality, leading to $-1.6 \%$ and $-4.8 \%$ declines, and $0.6 \%$

311 and $2.2 \%$ increases, in projected coral cover over 7 years, respectively.

312

\section{Discussion}

314 The present study utilizes an IBM developed for a fore reef coral community to evaluate how the

315 effects of $\mathrm{OA}$ (i.e., $\sim 1100-1200 \mu \mathrm{atm} \mathrm{pCO}_{2}$ ) on coral growth and competition among corals scale

316 up to impact the projected rate of increase in coral cover following a major disturbance. Under

317 current ambient $\mathrm{pCO}_{2}$, the coral community at 10-m depth on the fore reef of Mo'orea has

318 quickly recovered from recent disturbances, with coral cover rising from $0.3 \%$ in 2010 to $66 \%$ in

319 2016, primarily through high recruitment of Pocillopora (Tsounis \& Edmunds, 2016; Edmunds,

320 2018b). However, the present simulations suggest that the rate of coral recovery over 7 years

321 following a severe disturbance will be slowed by $56 \%$ under an OA regime of $\sim 1000-1200 \mu$ atm

$322 \mathrm{pCO}_{2}$, relative to the recovery rate observed under present conditions from 2010 to 2016, with

323 coral cover reaching $29 \%$ under OA after 7 years. Conversely, when the effects of OA were only

324 applied to linear growth rates of corals, and not competition among corals, coral cover reached

$32543 \%$ after 7 years, $49 \%$ higher than the recovery when the effects of OA were implemented on

326 both growth and competition among corals. The present analyses reveal the high potential for an

327 IBM approach to improve understand of the extent to which coral cover will change in the

328 future. Using a series of simplified assumptions and a limited set of empirical data to inform the

329 model, the results indicate a strong effect of altered coral-coral competition under OA on coral

330 community dynamics. Indeed, while elevated $\mathrm{pCO}_{2}$ may not result in high rates of coral

331 mortality, model projections suggest multiple pathways, including reduce colony growth and

332 altered coral-coral competition, by which OA can slow coral community recovery following 
333 large-scale mortality events affecting reef-building corals.

334 There is a consensus that the growth rates of most scleractinians will be negatively

335 impacted by OA (Chan \& Connolly, 2013; Kroeker et al., 2013), yet these results, mostly from

336 experiments in which colonies have been grown in isolation (i.e., without touching other

337 colonies), have the potential to be modified by interactions among corals of the same or different

338 species (Evensen, Edmunds \& Sakai, 2015; Evensen \& Edmunds, 2016; Horwitz, Hoogenboom

$339 \&$ Fine, 2017). When the effects of OA on coral growth alone were included in the present

340 projections, the rate of increase in coral cover was reduced by $39-54 \%$ for Pocillopora,

341 Montipora, and Acropora relative to present day $\mathrm{pCO}_{2}$ conditions. Conversely, the cover of

342 Porites increased by $70 \%$ after 7 years, as our model assumed the growth rate of this genus was

343 unaffected by OA (Edmunds, Brown \& Moriarty, 2012; Comeau et al., 2014a; Edmunds \&

344 Yarid, 2017). It is important to note, however, that this assumption may be specific to Mo'orea,

345 as studies conducted elsewhere have indicated a negative impact of OA on the growth of massive

346 Porites (Krief et al., 2010). Nonetheless, the projected increase in cover of Porites in the present

347 study likely was due to alleviated competitive interactions with the other coral genera. Natural

$348 \mathrm{CO}_{2}$ vents in Papua New Guinea have highlighted the potential for Porites to benefit from

349 alleviated coral-coral competition under elevated $\mathrm{pCO}_{2}$ conditions. Massive Porites increased in

350 cover on reefs where $\mathrm{pCO}_{2}$ reaches $\sim 950 \mu$ atm and few other coral species were found, relative

351 to nearby reefs experiencing ambient $\mathrm{pCO}_{2}$ where coral cover and diversity were higher

352 (Fabricius et al., 2011), and thus competitive interactions with other corals were more likely to

353 occur. Indeed, when the effects of OA for both coral growth and coral-coral competition were

354 included in the present model, the cover of Porites decreased by $29 \%$ relative to present day

$355 \mathrm{pCO}_{2}$ conditions, with Pocillopora projected to persist on these reefs. 
resulted in further reduction in recovery for the other genera, ranging from a $53 \%$ reduction in cover after 7 years for Pocillopora, to a $79 \%$ decrease for Montipora relative to present day conditions over the same period. Together, this led to a reduction in rate of increase in cover of the coral community to $\sim 5 \% \mathrm{y}^{-1}$, compared to $11 \% \mathrm{y}^{-1}$ under ambient conditions. Pocillopora was the only genus to exceed $3 \%$ cover at the end of the projections under OA, reaching $23.4 \%$ cover. Indeed, although Pocillopora spp. has often been considered sensitive to acute disturbances (Gleason, 1993; Darling et al., 2012), Pocillopora spp. appears to be a diverse genus (i.e., consisting of at least six species including $P$. verrucosa and $P$. meandrina [Edmunds et al., 2016b; Burgess et al., 2021]) that has overcome acute disturbances through high rates of recruitment in the 2-3 years following cessation of the COTs outbreak and cyclone Oli

367 (Bramanti \& Edmunds, 2016). High recruitment of Pocillopora on the fore reef of Mo'orea has resulted in a rate of increase in coral cover that exceeds that of any Indo-Pacific fore reef sites to date (Graham et al., 2011). Through larval connectivity, the projected persistence of this genus under OA could prove beneficial for other reefs in the region, because Pocillopora is ubiquitous across the Society Islands and throughout the tropical Eastern Pacific (Magalon, Adjeroud \& Veuille, 2005; Edmunds et al., 2016b). to persistence in this fore reef habitat under the OA regime tested, at least as evaluated from the

375 low cover $(<2.5 \%)$ established within 7 years of a major disturbance. Acropora and Montipora

376 typically are sensitive to chronic and acute stressors (Darling et al., 2012), and yet these genera

377 include some of the most ecologically important species on Indo-Pacific reefs, notably within

378 Acropora (Graham \& Nash, 2013). In the present study, it is possible that Acropora were 
379 underrepresented in the model projections, however, as the model did not account for the

380 positive density-dependent recruitment observed for Acropora on the fore reef of Mo'orea

381 (Bramanti \& Edmunds, 2016). Positive density-dependent recruitment would favour recovery of

382 Acropora populations as cover of this genus increases (Kayal et al., 2018). Still, the cover of

383 Acropora and Montipora has remained low on the fore reef of Mo'orea since 2010 (Adjeroud et

384 al., 2018), potentially resigning these genera to becoming ecological 'ghosts' (sensu Hull et al., $3852015)$ at a local scale.

386 To implement an IBM to project coral cover in the present analysis, it was necessary to

387 accept several limitations regarding the empirical data with which the model would be informed.

388 Indeed, the necessity of adjusting recruitment rates to bring projected cover to within $1 \%$ of

389 empirical cover highlights how little is known about the factors causing coral recruitment to

390 greatly vary among years (Edmunds, Leichter \& Adjeroud, 2010), or how this variation

391 modulates changes in coral cover. Nevertheless, the adjustment to recruitment was highly

392 effective for the dominant genus, Pocillopora. Additionally, there were uncertainties associated

393 with quantifying the effects of OA on vital rates, while consideration of the effects of OA on

394 algal dynamics (e.g., on algal productivity, grazing dynamics, and coral-algal competition) was

395 beyond the scope of the study. While macroalgae often can pre-empt space and limit coral

396 recruitment on many reefs following disturbances (Bender, Diaz-Pulido \& Dove, 2012; Evensen

397 et al., 2019), macroalgae were not considered a major competitor for space in the present model, 398 as there has been no evidence of macroalgal overgrowth on the fore reef of Mo'orea, even after

399 the acute disturbances created by COTs and Cyclone Oli (Adam et al., 2011). Mo'orea may be a

400 special case in this regard, because fish herbivory at 12-m depth on the fore reef in 2010 was

401 sufficient to prevent macroalgal proliferation on reefs recently denuded of coral (Holbrook et al., 
402 2016). While the lack of macroalgae in the model may still be representative of reefs where

403 herbivores are abundant, the outcome of competition under OA may be different on reefs that

404 lack adequate herbivory. Indeed, some macroalgae can benefit from increases in $\mathrm{CO}_{2}$ and/or

$405 \mathrm{HCO}_{3}{ }^{-}$under OA (Koch et al., 2013; Diaz-Pulido \& Barrón, 2020; Ho et al., 2021), enhancing

406 the competitive ability of macroalgae versus corals, and possibly increasing macroalgal

407 dominance on reefs under OA (Anthony et al., 2011; Diaz-Pulido et al., 2011; Johnson et al.,

408 2012). As such, it is important that future studies to build on the present approach with more

409 sophisticated models (i.e., that may include macroalgal dynamics where applicable) that can be

410 developed as suitable empirical data become available.

411 Our model also did not consider the possibility for acclimatization or adaptation of corals

412 to reduce their sensitivity to elevated $\mathrm{pCO}_{2}$, which may have resulted in more pessimistic

413 projections of coral cover. We also did not account for the potential of depressed coral

414 recruitment under elevated $\mathrm{pCO}_{2}$ (Doropoulos et al., 2012; Fabricius et al., 2017), which, in

415 contrast to the possible positive effects of acclimatization and adaptation, may have favoured

416 optimistic projections of coral cover. Indeed, sensitivity analysis suggest that coral recruitment

417 can strongly affect projected coral cover, with a $20 \%$ decline in recruitment resulted in a $\sim 15 \%$

418 decline in coral cover after 7 years. Lastly, the frequency and severity of bleaching events will

419 almost certainly increase as ocean warming continues (Heron et al., 2016), further challenging

420 the capacity of the coral community to maintain its resilience, possibly as has occurred following

421 severe bleaching in 2019 (Burgess et al., 2021). Despite the aforementioned limitations of the

422 present study, the outcome of this modelling effort provides an important advance towards

423 understanding the impacts of OA on corals at a reef-scale. Clearly, more data on the effects of

424 OA on coral vital rates and coral reef community processes are required, however, to better 
425 parameterise the models, effectively capture ecological realism, and improve the accuracy of

426 model projections under climate change conditions.

427

428 Acknowledgments

429 We would like to thank members of the CSUN Polyp lab who helped collect empirical data used 430 to parameterize the model. We would also like to thank J.-C. Ortiz who helped adapt the model 431 to include empirical data from Mo'orea, and members of the Marine Spatial Ecology Lab whose 432 feedback helped shape this study. This work was funded by ARC and NESP grants to PJM, and 433 funding from the National Science Foundation to the MCR-LTER (OCE 16-37396) and for OA 434 research (OCE 14-15268). This is contribution number xxx of the Marine Biology Program of 435 California State University, Northridge. 


\section{References}

437 Adam TC, Schmitt RJ, Holbrook SJ, Brooks AJ, Edmunds PJ, Carpenter RC, Bernardi G. 2011. Herbivory, connectivity, and ecosystem resilience: response of a coral reef to a largescale perturbation. PLOS ONE 6:e23717. DOI: 10.1371/journal.pone.0023717.

Adjeroud M, Kayal M, Iborra-Cantonnet C, Vercelloni J, Bosserelle P, Liao V, Chancerelle Y,

Albright R, Langdon C. 2011. Ocean acidification impacts multiple early life history processes of the Caribbean coral Porites astreoides. Global Change Biology 17:2478-2487. DOI: 10.1111/j.1365-2486.2011.02404.x.

Anthony KRN, Maynard JA, Diaz-Pulido G, Mumby PJ, Marshall PA, Cao L, Hoegh-Guldberg Change Biology 17:1798-1808. DOI: https://doi.org/10.1111/j.1365-2486.2010.02364.x.

Bender D, Diaz-Pulido G, Dove S. 2012. Effects of macroalgae on corals recovering from disturbance. Journal of Experimental Marine Biology and Ecology 429:15-19. DOI: 10.1016/j.jembe.2012.06.014.

Bosserelle P, Berteaux-Lecellier V, Chancerelle Y, Hédouin L, Nugues M, Wallace C, Pichon P. 2014. Guide d'identification des coraux de Moorea. CRIOBE.

Bozec Y-M, Doropoulos C, Roff G, Mumby PJ. 2019. Transient grazing and the dynamics of an 456 unanticipated coral-algal phase shift. Ecosystems. DOI: 10.1007/s10021-018-0271-z. 
457 Bozec Y-M, O’Farrell S, Bruggemann JH, Luckhurst BE, Mumby PJ. 2016. Tradeoffs between 458 fisheries harvest and the resilience of coral reefs. Proceedings of the National Academy of Sciences 113:4536-4541. DOI: 10.1073/pnas.1601529113.

460

461

462

463

464

465

466

467

468

469

470

471

472

473

474

475

476

477

478

479

Bramanti L, Edmunds PJ. 2016. Density-associated recruitment mediates coral population dynamics on a coral reef. Coral Reefs 35:543-553. DOI: 10.1007/s00338-016-1413-4.

Burgess SC, Johnston EC, Wyatt ASJ, Leichter JJ, Edmunds PJ. 2021. Response diversity in corals: hidden differences in bleaching mortality among cryptic Pocillopora species. Ecology:Accepted.

Chan NCS, Connolly SR. 2013. Sensitivity of coral calcification to ocean acidification: a metaanalysis. Global Change Biology 19:282-290. DOI: 10.1111/gcb.12011.

Comeau S, Carpenter RC, Nojiri Y, Putnam HM, Sakai K, Edmunds PJ. 2014a. Pacific-wide contrast highlights resistance of reef calcifiers to ocean acidification. Proceedings of the Royal Society B: Biological Sciences 281:20141339-20141339. DOI: 10.1098/rspb.2014.1339.

Comeau S, Edmunds PJ, Spindel NB, Carpenter RC. 2014b. Fast coral reef calcifiers are more sensitive to ocean acidification in short-term laboratory incubations. Limnology and Oceanography 59:1081-1091. DOI: 10.4319/1o.2014.59.3.1081.

Connell JH, Hughes TP, Wallace CC, Tanner JE, Harms KE, Kerr AM. 2004. A Long-Term Study of Competition and Diversity of Corals. Ecological Monographs 74:179-210. DOI: https://doi.org/10.1890/02-4043.

Dai C-F. 1990. Interspecific competition in Taiwanese corals with special reference to interactions between alcyonaceans and scleractinians. Marine Ecology Progress Series 60:291-297. DOI: 10.3354/meps060291. 
480 Darling ES, Alvarez-Filip L, Oliver TA, McClanahan TR, Côté IM. 2012. Evaluating life-history $481 \quad$ strategies of reef corals from species traits. Ecology Letters 15:1378-1386. DOI:

482

483 Diaz-Pulido G, Barrón C. 2020. $\mathrm{CO}_{2}$ Enrichment Stimulates Dissolved Organic Carbon Release 484 in Coral Reef Macroalgae. Journal of Phycology 56:1039-1052. DOI:

485 https://doi.org/10.1111/jpy.13002.

486 Diaz-Pulido G, Gouezo M, Tilbrook B, Dove S, Anthony KRN. 2011. High $\mathrm{CO}_{2}$ enhances the 487 competitive strength of seaweeds over corals. Ecology Letters 14:156-162. DOI: https://doi.org/10.1111/j.1461-0248.2010.01565.x.

Doropoulos C, Ward S, Diaz-Pulido G, Hoegh-Guldberg O, Mumby PJ. 2012. Ocean acidification reduces coral recruitment by disrupting intimate larval-algal settlement interactions. Ecology Letters 15:338-346. DOI: 10.1111/j.1461-0248.2012.01743.x.

Edmunds PJ. 2018a. MCR LTER: Coral Reef: long-term population and community dynamics: corals, ongoing since 2005. DOI: 10.6073/pasta/1 f05f1f52a2759dc096da9c24e88b1e8.

494 Edmunds PJ. 2018b. Implications of high rates of sexual recruitment in driving rapid reef recovery in Mo'orea, French Polynesia. Scientific Reports 8. DOI: 10.1038/s41598-01834686-z.

497

498

499

500

501 502

Edmunds PJ. 2021. Spatiotemporal variation in coral recruitment and its association with seawater temperature. Limnology and Oceanography:lno.11693. DOI: 10.1002/lno.11693.

Edmunds PJ, Brown D, Moriarty V. 2012. Interactive effects of ocean acidification and temperature on two scleractinian corals from Moorea, French Polynesia. Global Change Biology 18:2173-2183. DOI: 10.1111/j.1365-2486.2012.02695.x. 
503 Edmunds PJ, Comeau S, Lantz C, Andersson A, Briggs C, Cohen A, Gattuso J-P, Grady JM,

504 Gross K, Johnson M, Muller EB, Ries JB, Tambutté S, Tambutté E, Venn A, Carpenter

505

506 tropical coral reefs. BioScience 66:350-362. DOI: 10.1093/biosci/biw023.

507 Edmunds PJ, Leichter JJ, Adjeroud M. 2010. Landscape-scale variation in coral recruitment in Moorea, French Polynesia. Marine Ecology Progress Series 414:75-89. DOI:

Edmunds PJ, Leichter JJ, Johnston EC, Tong EJ, Toonen RJ. 2016b. Ecological and genetic variation in reef-building corals on four Society Islands: Coral reefs in French Polynesia. Limnology and Oceanography 61:543-557. DOI: 10.1002/1no.10231.

513 Edmunds PJ, Yarid A. 2017. The effects of ocean acidification on wound repair in the coral Porites spp. Journal of Experimental Marine Biology and Ecology 486:98-104. DOI: 10.1016/j.jembe.2016.10.001.

Evensen NR, Doropoulos C, Morrow KM, Motti CA, Mumby PJ. 2019. Inhibition of coral settlement at multiple spatial scales by a pervasive algal competitor. Marine Ecology Progress Series 612:29-42. DOI: https://doi.org/10.3354/meps12879.

Evensen NR, Edmunds PJ. 2016. Interactive effects of ocean acidification and neighboring corals on the growth of Pocillopora verrucosa. Marine Biology 163:148. DOI: 10.1007/s00227-016-2921-z.

522 Evensen NR, Edmunds PJ, Sakai K. 2015. Effects of $\mathrm{pCO}_{2}$ on spatial competition between the 523 corals Montipora aequituberculata and Porites lutea. Marine Ecology Progress Series 541:123-134. DOI: 10.3354/meps11512. 
525 Fabricius KE, Langdon C, Uthicke S, Humphrey C, Noonan S, De'ath G, Okazaki R,

526 Muehllehner N, Glas MS, Lough JM. 2011. Losers and winners in coral reefs acclimatized to elevated carbon dioxide concentrations. Nature Climate Change 1:165-

528 169. DOI: $10.1038 /$ nclimate1 122.

529

530

531

532

533

534

535

536

537

538

539

540

541

542

543

544

545

546

547

Fabricius KE, Noonan SHC, Abrego D, Harrington L, De'ath G. 2017. Low recruitment due to altered settlement substrata as primary constraint for coral communities under ocean acidification. Proceedings of the Royal Society B: Biological Sciences 284:20171536. DOI: $10.1098 / \mathrm{rspb} .2017 .1536$.

Gleason MG. 1993. Effects of disturbance on coral communities: bleaching in Moorea, French Polynesia. Coral Reefs 12:193-201. DOI: 10.1007/BF00334479.

Graham NAJ, Nash KL. 2013. The importance of structural complexity in coral reef ecosystems. Coral Reefs 32:315-326. DOI: 10.1007/s00338-012-0984-y.

Graham NAJ, Nash KL, Kool JT. 2011. Coral reef recovery dynamics in a changing world. Coral Reefs 30:283-294. DOI: 10.1007/s00338-010-0717-z.

Heron SF, Maynard JA, van Hooidonk R, Eakin CM. 2016. Warming Trends and Bleaching Stress of the World's Coral Reefs 1985-2012. Scientific Reports 6:38402. DOI: $10.1038 /$ srep38402.

Ho M, McBroom J, Bergstrom E, Diaz-Pulido G. 2021. Physiological responses to temperature and ocean acidification in tropical fleshy macroalgae with varying affinities for inorganic carbon. ICES Journal of Marine Science 78:89-100. DOI: 10.1093/icesjms/fsaa195.

Holbrook SJ, Adam TC, Edmunds PJ, Schmitt RJ, Carpenter RC, Brooks AJ, Lenihan HS, Briggs CJ. 2018. Recruitment drives spatial variation in recovery rates of resilient coral reefs. Scientific Reports 8:7338. DOI: 10.1038/s41598-018-25414-8. 
548 Holbrook SJ, Schmitt RJ, Adam TC, Brooks AJ. 2016. Coral reef resilience, tipping points and

549 the strength of herbivory. Scientific Reports 6:35817. DOI: $10.1038 /$ srep35817.

550 Horwitz R, Hoogenboom MO, Fine M. 2017. Spatial competition dynamics between reef corals 551 under ocean acidification. Scientific Reports 7:40288. DOI: 10.1038/srep40288.

552 Hughes TP, Barnes ML, Bellwood DR, Cinner JE, Cumming GS, Jackson JBC, Kleypas J, van 553 de Leemput IA, Lough JM, Morrison TH, Palumbi SR, van Nes EH, Scheffer M. 2017.

Hull PM, Darroch SAF, Erwin DH. 2015. Rarity in mass extinctions and the future of ecosystems. Nature 528:345-351. DOI: 10.1038/nature16160.

Johnson VR, Russell BD, Fabricius KE, Brownlee C, Hall-Spencer JM. 2012. Temperate and tropical brown macroalgae thrive, despite decalcification, along natural $\mathrm{CO}_{2}$ gradients. Global Change Biology 18:2792-2803. DOI: https://doi.org/10.1111/j.13652486.2012.02716.x.

561

562

563

564

565

566

Kayal M, Lenihan HS, Brooks AJ, Holbrook SJ, Schmitt RJ, Kendall BE. 2018. Predicting coral community recovery using multi-species population dynamics models. Ecology Letters 21:1790-1799. DOI: 10.1111/ele.13153.

Kayal M, Vercelloni J, Lison de Loma T, Bosserelle P, Chancerelle Y, Geoffroy S, Stievenart C, Michonneau F, Penin L, Planes S, Adjeroud M. 2012. Predator Crown-of-Thorns starfish (Acanthaster planci) outbreak, mass mortality of corals, and cascading effects on reef fish and benthic communities. PLoS ONE 7:e47363. DOI: 10.1371/journal.pone.0047363.

Koch M, Bowes G, Ross C, Zhang X-H. 2013. Climate change and ocean acidification effects on seagrasses and marine macroalgae. Global Change Biology 19:103-132. DOI: https://doi.org/10.1111/j.1365-2486.2012.02791.x. 
571 Kornder NA, Riegl BM, Figueiredo J. 2018. Thresholds and drivers of coral calcification

572 responses to climate change. Global Change Biology 24:5084-5095. DOI:

573 10.1111/gcb.14431.

574

575

576

577

578

579

580

581

582

583

584

585

586

587

588

589

590

591

592

Krief S, Hendy EJ, Fine M, Yam R, Meibom A, Foster GL, Shemesh A. 2010. Physiological and isotopic responses of scleractinian corals to ocean acidification. Geochimica et Cosmochimica Acta 74:4988-5001. DOI: 10.1016/j.gca.2010.05.023.

Kroeker KJ, Kordas RL, Crim R, Hendriks IE, Ramajo L, Singh GS, Duarte CM, Gattuso J-P. 2013. Impacts of ocean acidification on marine organisms: quantifying sensitivities and interaction with warming. Global Change Biology 19:1884-1896. DOI: 10.1111/gcb.12179.

Kroeker KJ, Kordas RL, Crim RN, Singh GG. 2010. Meta-analysis reveals negative yet variable effects of ocean acidification on marine organisms: biological responses to ocean acidification. Ecology Letters 13:1419-1434. DOI: 10.1111/j.1461-0248.2010.01518.x.

Kurihara H, Suhara Y, Mimura I, Golbuu Y. 2020. Potential acclimatization and adaptive responses of adult and trans-generation coral larvae from a naturally acidified habitat. Frontiers in Marine Science 7. DOI: 10.3389/fmars.2020.581160.

Lenihan HS, Kayal M. 2015. MCR LTER: Coral Reef: long-term coral population and community dynamics: annual island wide coral demography survey 2011 to present. DOI: $10.6073 /$ pasta/98855475790bfb012066f9dc802ecc31.

Magalon H, Adjeroud M, Veuille M. 2005. Patterns of genetic variation do not correlate with geographical distance in the reef-building coral Pocillopora meandrina in the South Pacific. Molecular Ecology 14:1861-1868. DOI: 10.1111/j.1365-294X.2005.02430.x. 
593 Muko S, Arakaki S, Tamai R, Sakai K. 2014. An individual-based model for population viability

594 analysis of the brooding coral Seriatopora hystrix. Ecological Modelling 277:68-76.

595 DOI: 10.1016/j.ecolmodel.2014.01.025.

596 Mumby PJ, Hastings A, Edwards HJ. 2007. Thresholds and the resilience of Caribbean coral 597 reefs. Nature 450:98-101. DOI: 10.1038/nature06252.

598 Ortiz JC, Bozec Y-M, Wolff NH, Doropoulos C, Mumby PJ. 2014. Global disparity in the 599 ecological benefits of reducing carbon emissions for coral reefs. Nature Climate Change 600 4:1090-1094. DOI: 10.1038/nclimate2439.

601 Sandin SA, McNamara DE. 2012. Spatial dynamics of benthic competition on coral reefs.

602 Oecologia 168:1079-1090. DOI: 10.1007/s00442-011-2156-0.

603 Schoepf V, Jury CP, Toonen RJ, McCulloch MT. 2017. Coral calcification mechanisms facilitate 604 adaptive responses to ocean acidification. Proceedings of the Royal Society B: Biological 605 Sciences 284:20172117. DOI: 10.1098/rspb.2017.2117.

Tsounis G, Edmunds PJ. 2016. The potential for self-seeding by the coral Pocillopora spp. in Moorea, French Polynesia. PeerJ 4:e2544. DOI: 10.7717/peerj.2544.

608 Wickham H. 2016. ggplot2: Elegant Graphics for Data Analysis. Springer.

609 Wittmann AC, Pörtner H-O. 2013. Sensitivities of extant animal taxa to ocean acidification.

$610 \quad$ Nature Climate Change 3:995-1001. DOI: 10.1038/nclimate1982.

611

612 Adjeroud M, Kayal M, Iborra-Cantonnet C, Vercelloni J, Bosserelle P, Liao V, Chancerelle Y, 613 Claudet J, Penin L. 2018. Recovery of coral assemblages despite acute and recurrent 614 disturbances on a South Central Pacific reef. Scientific Reports 8. DOI: 10.1038/s41598$615 \quad 018-27891-3$. 
616 Albright R, Langdon C. 2011. Ocean acidification impacts multiple early life history processes

617 of the Caribbean coral Porites astreoides. Global Change Biology 17:2478-2487. DOI:

$618 \quad$ 10.1111/j.1365-2486.2011.02404.x.

619 Anthony KRN, Maynard JA, Diaz-Pulido G, Mumby PJ, Marshall PA, Cao L, Hoegh-Guldberg

620 O. 2011. Ocean acidification and warming will lower coral reef resilience. Global

621 Change Biology 17:1798-1808. DOI: https://doi.org/10.1111/j.1365-2486.2010.02364.x.

622 Bender D, Diaz-Pulido G, Dove S. 2012. Effects of macroalgae on corals recovering from

623

624 disturbance. Journal of Experimental Marine Biology and Ecology 429:15-19. DOI: 10.1016/j.jembe.2012.06.014.

Bosserelle P, Berteaux-Lecellier V, Chancerelle Y, Hédouin L, Nugues M, Wallace C, Pichon P. 2014. Guide d'identification des coraux de Moorea. CRIOBE.

Bozec Y-M, Doropoulos C, Roff G, Mumby PJ. 2019. Transient grazing and the dynamics of an unanticipated coral-algal phase shift. Ecosystems. DOI: 10.1007/s10021-018-0271-z.

Bozec Y-M, O’Farrell S, Bruggemann JH, Luckhurst BE, Mumby PJ. 2016. Tradeoffs between Sciences 113:4536-4541. DOI: 10.1073/pnas.1601529113.

Bramanti L, Edmunds PJ. 2016. Density-associated recruitment mediates coral population dynamics on a coral reef. Coral Reefs 35:543-553. DOI: 10.1007/s00338-016-1413-4.

Burgess SC, Johnston EC, Wyatt ASJ, Leichter JJ, Edmunds PJ. 2021. Response diversity in corals: hidden differences in bleaching mortality among cryptic Pocillopora species. Ecology:Accepted.

637 Chan NCS, Connolly SR. 2013. Sensitivity of coral calcification to ocean acidification: a meta638 analysis. Global Change Biology 19:282-290. DOI: 10.1111/gcb.12011. 
639 Comeau S, Carpenter RC, Nojiri Y, Putnam HM, Sakai K, Edmunds PJ. 2014a. Pacific-wide 640 contrast highlights resistance of reef calcifiers to ocean acidification. Proceedings of the 641 Royal Society B: Biological Sciences 281:20141339-20141339. DOI:

$642 \quad 10.1098 /$ rspb.2014.1339.

643 Comeau S, Edmunds PJ, Spindel NB, Carpenter RC. 2014b. Fast coral reef calcifiers are more 644 sensitive to ocean acidification in short-term laboratory incubations. Limnology and 645 Oceanography 59:1081-1091. DOI: 10.4319/1o.2014.59.3.1081.

646 Connell JH, Hughes TP, Wallace CC, Tanner JE, Harms KE, Kerr AM. 2004. A Long-Term 647 Study of Competition and Diversity of Corals. Ecological Monographs 74:179-210. 648 DOI: https://doi.org/10.1890/02-4043.

649 Dai C-F. 1990. Interspecific competition in Taiwanese corals with special reference to 650 interactions between alcyonaceans and scleractinians. Marine Ecology Progress Series 651 60:291-297. DOI: 10.3354/meps060291.

652 Darling ES, Alvarez-Filip L, Oliver TA, McClanahan TR, Côté IM. 2012. Evaluating life-history 653 strategies of reef corals from species traits. Ecology Letters 15:1378-1386. DOI: $654 \quad$ 10.1111/j.1461-0248.2012.01861.x.

655 Diaz-Pulido G, Gouezo M, Tilbrook B, Dove S, Anthony KRN. 2011. High $\mathrm{CO}_{2}$ enhances the 656 competitive strength of seaweeds over corals. Ecology Letters 14:156-162. DOI:

657 https://doi.org/10.1111/j.1461-0248.2010.01565.x.

658 Doropoulos C, Ward S, Diaz-Pulido G, Hoegh-Guldberg O, Mumby PJ. 2012. Ocean 659 acidification reduces coral recruitment by disrupting intimate larval-algal settlement 660 interactions. Ecology Letters 15:338-346. DOI: 10.1111/j.1461-0248.2012.01743.x. 
661 Edmunds PJ. 2018a. MCR LTER: Coral Reef: long-term population and community dynamics:

662 corals, ongoing since 2005. DOI: 10.6073/pasta/1f05f1f52a2759dc096da9c24e88b1e8.

663 Edmunds PJ. 2018b. Implications of high rates of sexual recruitment in driving rapid reef 664

665 recovery in Mo'orea, French Polynesia. Scientific Reports 8. DOI: 10.1038/s41598-018-

Edmunds PJ. 2021. Spatiotemporal variation in coral recruitment and its association with 34686-z.

668 seawater temperature. Limnology and Oceanography:lno.11693. DOI:

669

Edmunds PJ, Brown D, Moriarty V. 2012. Interactive effects of ocean acidification and temperature on two scleractinian corals from Moorea, French Polynesia. Global Change Biology 18:2173-2183. DOI: 10.1111/j.1365-2486.2012.02695.x.

672 Edmunds PJ, Comeau S, Lantz C, Andersson A, Briggs C, Cohen A, Gattuso J-P, Grady JM, Gross K, Johnson M, Muller EB, Ries JB, Tambutté S, Tambutté E, Venn A, Carpenter RC. 2016a. Integrating the effects of ocean acidification across functional scales on tropical coral reefs. BioScience 66:350-362. DOI: 10.1093/biosci/biw023.

Edmunds PJ, Leichter JJ, Adjeroud M. 2010. Landscape-scale variation in coral recruitment in Moorea, French Polynesia. Marine Ecology Progress Series 414:75-89. DOI:

678 10.3354/meps08728.

Edmunds PJ, Leichter JJ, Johnston EC, Tong EJ, Toonen RJ. 2016b. Ecological and genetic 680 variation in reef-building corals on four Society Islands: Coral reefs in French Polynesia. Limnology and Oceanography 61:543-557. DOI: 10.1002/lno.10231. 
682 Edmunds PJ, Yarid A. 2017. The effects of ocean acidification on wound repair in the coral 683 Porites spp. Journal of Experimental Marine Biology and Ecology 486:98-104. DOI: $684 \quad 10.1016 /$ j.jembe.2016.10.001.

685 Evensen NR, Doropoulos C, Morrow KM, Motti CA, Mumby PJ. 2019. Inhibition of coral 686 settlement at multiple spatial scales by a pervasive algal competitor. Marine Ecology 687 Progress Series 612:29-42. DOI: https://doi.org/10.3354/meps12879.

688 Evensen NR, Edmunds PJ. 2016. Interactive effects of ocean acidification and neighboring 689 corals on the growth of Pocillopora verrucosa. Marine Biology 163:148. DOI:

$690 \quad 10.1007 / \mathrm{s} 00227-016-2921-\mathrm{z}$.

691 Evensen NR, Edmunds PJ, Sakai K. 2015. Effects of $\mathrm{pCO}_{2}$ on spatial competition between the 692 corals Montipora aequituberculata and Porites lutea. Marine Ecology Progress Series

693 541:123-134. DOI: 10.3354/meps11512.

694 Fabricius KE, Langdon C, Uthicke S, Humphrey C, Noonan S, De'ath G, Okazaki R, 695 Muehllehner N, Glas MS, Lough JM. 2011. Losers and winners in coral reefs 696 acclimatized to elevated carbon dioxide concentrations. Nature Climate Change 1:165169. DOI: $10.1038 /$ nclimate1 122.

Fabricius KE, Noonan SHC, Abrego D, Harrington L, De'ath G. 2017. Low recruitment due to altered settlement substrata as primary constraint for coral communities under ocean acidification. Proceedings of the Royal Society B: Biological Sciences 284:20171536.

701 DOI: $10.1098 / \mathrm{rspb} .2017 .1536$.

702 Gleason MG. 1993. Effects of disturbance on coral communities: bleaching in Moorea, French 703 Polynesia. Coral Reefs 12:193-201. DOI: 10.1007/BF00334479. 
704 Graham NAJ, Nash KL. 2013. The importance of structural complexity in coral reef ecosystems.

705 Coral Reefs 32:315-326. DOI: 10.1007/s00338-012-0984-y.

706 Graham NAJ, Nash KL, Kool JT. 2011. Coral reef recovery dynamics in a changing world.

707 Coral Reefs 30:283-294. DOI: 10.1007/s00338-010-0717-z.

708 Heron SF, Maynard JA, van Hooidonk R, Eakin CM. 2016. Warming Trends and Bleaching

709 Stress of the World's Coral Reefs 1985-2012. Scientific Reports 6:38402. DOI:

$710 \quad 10.1038 / \operatorname{srep} 38402$.

711 Holbrook SJ, Adam TC, Edmunds PJ, Schmitt RJ, Carpenter RC, Brooks AJ, Lenihan HS,

712 Briggs CJ. 2018. Recruitment drives spatial variation in recovery rates of resilient coral

713 reefs. Scientific Reports 8:7338. DOI: 10.1038/s41598-018-25414-8.

714 Holbrook SJ, Schmitt RJ, Adam TC, Brooks AJ. 2016. Coral reef resilience, tipping points and 715 the strength of herbivory. Scientific Reports 6:35817. DOI: $10.1038 /$ srep35817.

716 Horwitz R, Hoogenboom MO, Fine M. 2017. Spatial competition dynamics between reef corals 717 under ocean acidification. Scientific Reports 7:40288. DOI: 10.1038/srep40288.

718 Hughes TP, Barnes ML, Bellwood DR, Cinner JE, Cumming GS, Jackson JBC, Kleypas J, van 719 de Leemput IA, Lough JM, Morrison TH, Palumbi SR, van Nes EH, Scheffer M. 2017.

720 Coral reefs in the Anthropocene. Nature 546:82-90. DOI: 10.1038 /nature22901.

721 Hull PM, Darroch SAF, Erwin DH. 2015. Rarity in mass extinctions and the future of 722 ecosystems. Nature 528:345-351. DOI: 10.1038/nature16160.

723 Kayal M, Lenihan HS, Brooks AJ, Holbrook SJ, Schmitt RJ, Kendall BE. 2018. Predicting coral 724 community recovery using multi-species population dynamics models. Ecology Letters 725 21:1790-1799. DOI: 10.1111/ele.13153. 
726 Kayal M, Vercelloni J, Lison de Loma T, Bosserelle P, Chancerelle Y, Geoffroy S, Stievenart C,

727

728

729

730

731

732

733

734

735

736

737

738

739

740

741

742

743

744

745

746

747

748

Michonneau F, Penin L, Planes S, Adjeroud M. 2012. Predator Crown-of-Thorns starfish (Acanthaster planci) outbreak, mass mortality of corals, and cascading effects on reef fish and benthic communities. PLOS ONE 7:e47363. DOI: 10.1371/journal.pone.0047363.

Kornder NA, Riegl BM, Figueiredo J. 2018. Thresholds and drivers of coral calcification responses to climate change. Global Change Biology 24:5084-5095. DOI: 10.1111/gcb.14431.

Kroeker KJ, Kordas RL, Crim R, Hendriks IE, Ramajo L, Singh GS, Duarte CM, Gattuso J-P. 2013. Impacts of ocean acidification on marine organisms: quantifying sensitivities and interaction with warming. Global Change Biology 19:1884-1896. DOI: 10.1111/gcb.12179.

Kroeker KJ, Kordas RL, Crim RN, Singh GG. 2010. Meta-analysis reveals negative yet variable effects of ocean acidification on marine organisms: biological responses to ocean acidification. Ecology Letters 13:1419-1434. DOI: 10.1111/j.1461-0248.2010.01518.x.

Kurihara H, Suhara Y, Mimura I, Golbuu Y. 2020. Potential acclimatization and adaptive responses of adult and trans-generation coral larvae from a naturally acidified habitat. Frontiers in Marine Science 7. DOI: 10.3389/fmars.2020.581160.

Lenihan HS, Kayal M. 2015. MCR LTER: Coral Reef: long-term coral population and community dynamics: annual island wide coral demography survey 2011 to present. DOI: $10.6073 /$ pasta/98855475790bfb012066f9dc802ecc31.

Magalon H, Adjeroud M, Veuille M. 2005. Patterns of genetic variation do not correlate with geographical distance in the reef-building coral Pocillopora meandrina in the South Pacific. Molecular Ecology 14:1861-1868. DOI: 10.1111/j.1365-294X.2005.02430.x. 
749 Muko S, Arakaki S, Tamai R, Sakai K. 2014. An individual-based model for population viability

$750 \quad$ analysis of the brooding coral Seriatopora hystrix. Ecological Modelling 277:68-76.

$751 \quad$ DOI: 10.1016/j.ecolmodel.2014.01.025.

752 Mumby PJ, Hastings A, Edwards HJ. 2007. Thresholds and the resilience of Caribbean coral 753 reefs. Nature 450:98-101. DOI: 10.1038/nature06252.

754 Ortiz JC, Bozec Y-M, Wolff NH, Doropoulos C, Mumby PJ. 2014. Global disparity in the 755 ecological benefits of reducing carbon emissions for coral reefs. Nature Climate Change

756 4:1090-1094. DOI: 10.1038/nclimate2439.

757

758

759

760

761

762

763

764

765

766 767

Sandin SA, McNamara DE. 2012. Spatial dynamics of benthic competition on coral reefs. Oecologia 168:1079-1090. DOI: 10.1007/s00442-011-2156-0.

Schoepf V, Jury CP, Toonen RJ, McCulloch MT. 2017. Coral calcification mechanisms facilitate adaptive responses to ocean acidification. Proceedings of the Royal Society B: Biological Sciences 284:20172117. DOI: 10.1098/rspb.2017.2117.

Tsounis G, Edmunds PJ. 2016. The potential for self-seeding by the coral Pocillopora spp. in Moorea, French Polynesia. PeerJ 4:e2544. DOI: 10.7717/peerj.2544.

Wickham H. 2016. ggplot2: Elegant Graphics for Data Analysis. Springer.

Wittmann AC, Pörtner H-O. 2013. Sensitivities of extant animal taxa to ocean acidification. Nature Climate Change 3:995-1001. DOI: 10.1038/nclimate1982. 


\section{Table $\mathbf{1}$ (on next page)}

Parameterization used to alter coral growth rates as a function of contact with conspecific and heterospecific coral competitors.

Under ambient conditions, change in growth as a function of contact with conspecifics is determined by a linear relationship (Equation 1, below) and change in growth as a function of contact with heterospecifics $\left(b_{h}\right)$ is determined by an exponential decay function (Equation 2, below). Under $\mathrm{OA}$, change in growth as a function of contact with conspecifics $\left(\mathrm{b}_{c}\right)$ and heterospecifics $\left(b_{h}\right)$ are determined by an exponential decay function (Equation 2$)$. Value are unitless as they represent proportional changes in lateral extension as the percent contact increases, compared to maximum growth reported in Table S1 (scaled from 0-1). 


\section{Tables}

2 Table 1. Parameterization used to alter coral growth rates as a function of contact with

3 conspecific and heterospecific coral competitors. Under ambient conditions, change in growth as

4 a function of contact with conspecifics is determined by Equation 1 (below) and change in

5 growth as a function of contact with heterospecifics $\left(b_{h}\right)$ is determined by Equation 2 (below).

6 Under OA, change in growth as a function of contact with conspecifics $\left(b_{c}\right)$ and heterospecifics

$7 \quad\left(b_{h}\right)$ are determined by Equation 2. Value are unitless as they represent proportional changes in

8 lateral extension as the percent contact increases, compared to maximum growth reported in

9 Table S1 (scaled from 0-1).

\begin{tabular}{|l|c|c|c|c|}
\hline Equation 1 & \multicolumn{4}{|c|}{$=1-a \times$ percent coral contact } \\
\hline Equation 2 & \multicolumn{3}{|c|}{$=\exp \times(-b \times$ percent coral contact $)$} \\
\hline RCP scenario & Acropora & Montipora & Pocillopora & Porites \\
\hline Ambient & $\begin{array}{c}\mathrm{a}=0.005 \\
\mathrm{~b}_{\mathrm{h}}=0.01\end{array}$ & $\begin{array}{c}\mathrm{a}=0.005 \\
\mathrm{~b}_{\mathrm{h}}=0.022\end{array}$ & $\begin{array}{c}\mathrm{a}=0.005 \\
\mathrm{~b}_{\mathrm{h}}=0.018\end{array}$ & $\begin{array}{c}\mathrm{a}=0.005 \\
\mathrm{~b}_{\mathrm{h}}=0.026\end{array}$ \\
\hline OA (RCP8.5) & $\mathrm{b}_{\mathrm{c}}=0.0097$ & $\begin{array}{c}\mathrm{b}_{\mathrm{c}}=0.0097 \\
\mathrm{~b}_{\mathrm{h}}=0.035\end{array}$ & $\begin{array}{c}\mathrm{b}_{\mathrm{c}}=0.0097 \\
\mathrm{~b}_{\mathrm{h}}=0.063\end{array}$ & $\begin{array}{c}\mathrm{b}_{\mathrm{c}}=0.0097 \\
\mathrm{~b}_{\mathrm{h}}=0.091\end{array}$ \\
\hline
\end{tabular}

10 


\section{Figure 1}

Measuring coral-coral competition in photoquadrats.

(a) Measurements of the diameters and circumferences of two Pocillopora colonies (black lines and circles) and their anticipated growth over 6 months (i.e., one model time step) (red circles), based on growth rates measured in experiments in Mo'orea ( $\mathrm{E}$ v e $\mathrm{n}$ s e $\mathrm{n} \&$ Edmunds, 2016). The blue line represents the distance between colony centres, with red dashed lines representing the anticipated radii of each colony after growth and the green lines representing the section (arc) of each colony in contact with the other colony after growth. (b) Using the distance between colony centres (Dist) and anticipated radii of each colony after growth $\left(R_{1}\right.$ and $\left.R_{2}\right)$ to calculate the height of the triangle $(H)$, which was then used to calculate the length of the contact arc between corals $\left(A_{1}\right.$ and $\left.A_{2}\right)$ using Heron's Formula (Weisstein, 2021) . (c) Average relationship between coral cover and the average percent contact among colonies (proportion of the perimeter of corals in contact with one or multiple colonies). Black circles represent the observed relationship between coral cover and contact from photoquadrats recorded at LTER1 from 2010-2015 $(n=65)$, while green circles and the darker green line represent the simulated relationship between coral cover and contact based on a random distribution of corals within a cell $(n=3400)$. Full details of the equations and code used to calculate and simulate coral competition are provided in Supplementary Material. 
a) Data extraction from photoquadrats

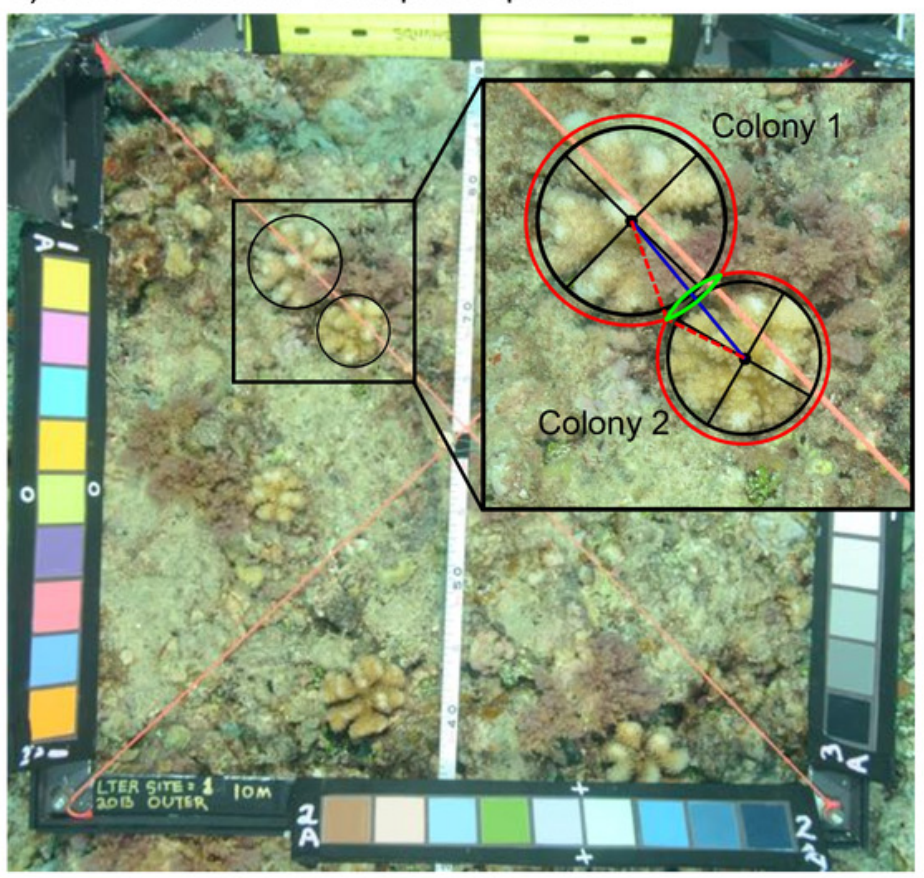

b) Calculating contact between corals

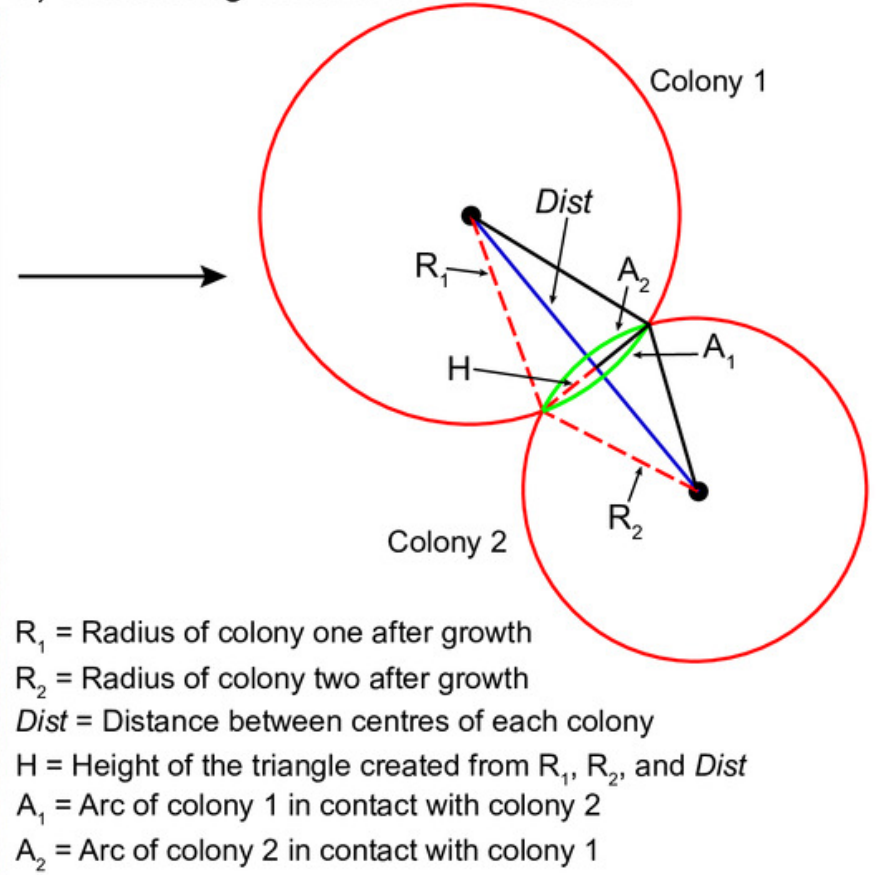

c) Average contact between colonies as a function of coral cover

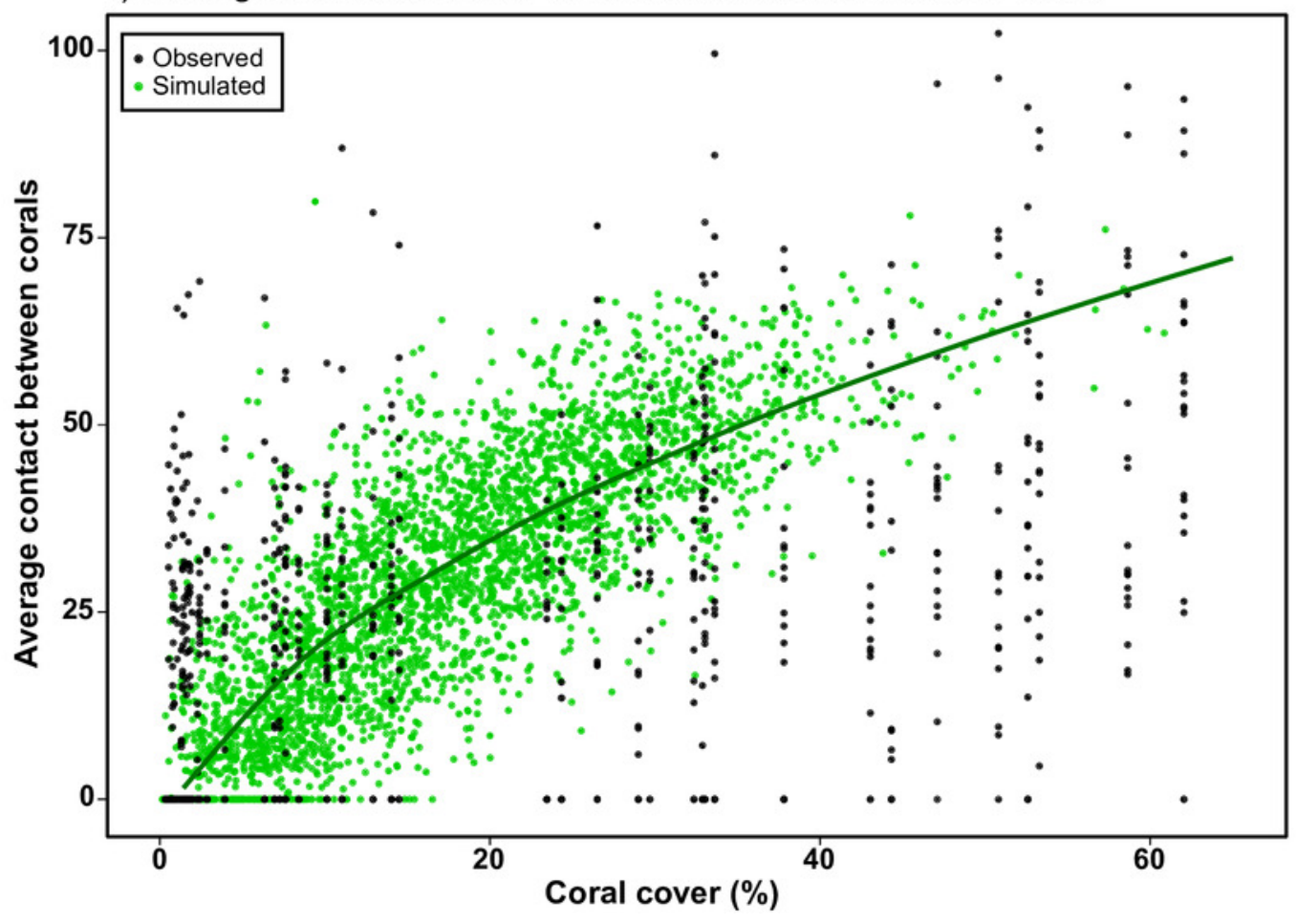




\section{Figure 2}

Determining coral linear growth rates as a function of competition.

(a) Photographs and diagram of the experimental set up from Evensen $\&$ Edmunds (2016) used to assess linear growth of Pocillopora verrucosa over $28 \mathrm{~d}$ as a function of contact with surrounding coral competitors, under ambient $(\sim 400 \mu \mathrm{atm})$ and elevated $\mathrm{pCO}_{2}(\sim 1030$ $\mu a t m$ ) in $500-L$ outdoor flumes (each $5.0 \times 0.3 \times 0.3 \mathrm{~m}$ ). Relationships between coral colony planar growth (as a proportion of the mean growth rate under ambient $\mathrm{pCO}_{2}$ conditions in the absence of competition) and percent of the perimeter of a colony in contact with conspecifics (b) and heterospecifics (c) under ambient $\mathrm{pCO}_{2}$ conditions ( $\left.\sim 400 \mu \mathrm{atm}\right)$, and contact with conspecifics (d) and heterospecifics (e) under elevated $\mathrm{pCO}_{2}$. Values are based on mean growth rates (larger black dots), with small grey dots representing individual replicates. Relationships within the measured values are represented by the solid black lines, with the extrapolation to $100 \%$ contact represented by the dotted line. Equations used to implement the effects of competition on colony growth are provided in Table 1. 
(a) Flume experiment
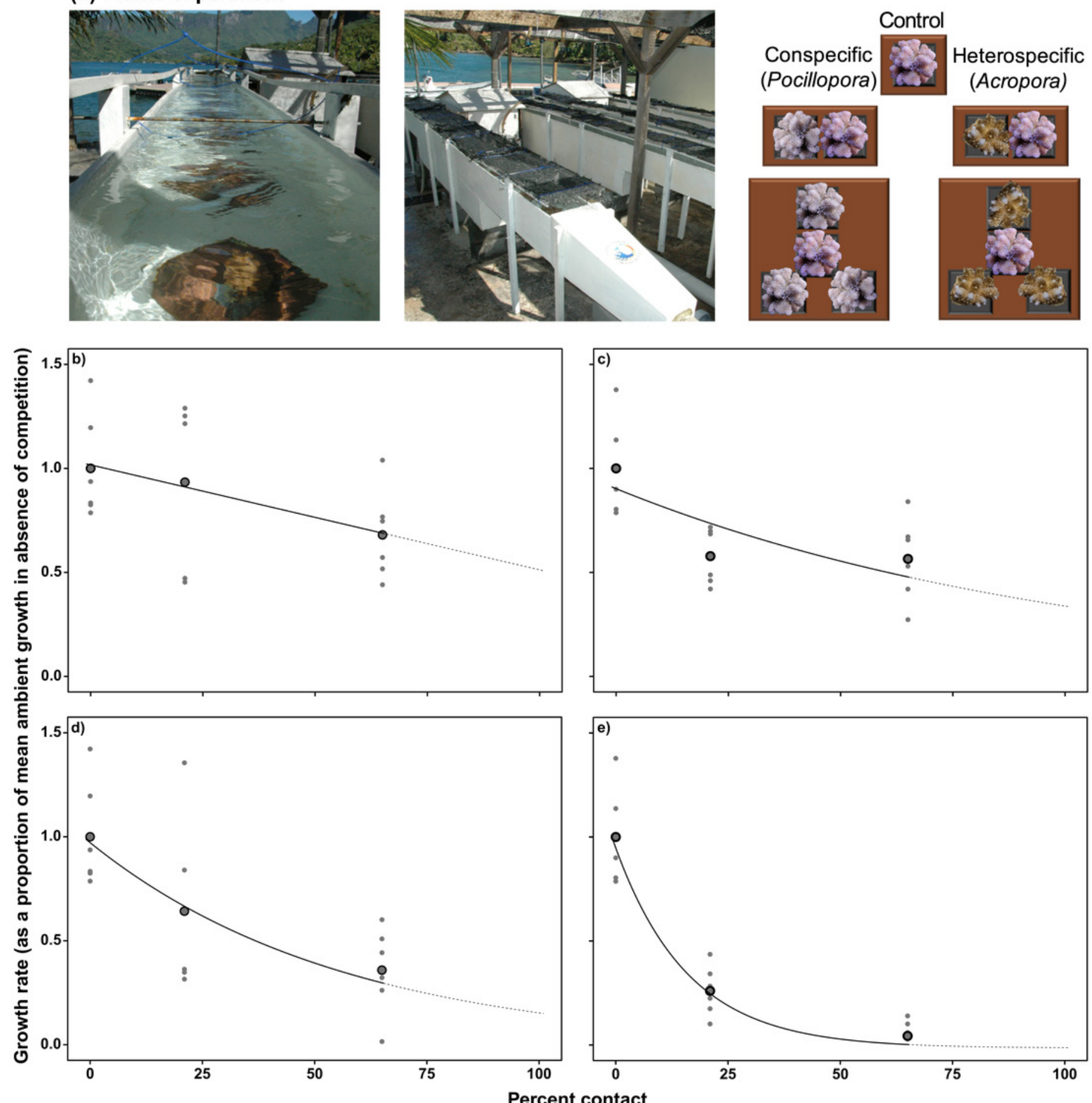


\section{Figure 3}

Description of empirical and modeled coral community recovery at 10-m depth, at site LTER1 on the fore reef of Mo'orea, French Polynesia.

(a) Short-term observations and simulations (7 years) of total coral cover. Grey dots show observed coral cover in individual photoquadrats, with black dots depicting annual means. Thin lines show simulations of the recovery under ambient conditions (blue), with the effects of OA on coral growth alone (orange), and with the effects of OA on both coral growth and competition among corals (red), with the mean trajectory represented by the thicker line ( $n$ = 100). (b) Observed (black) and simulated cover of each coral genus after the 7-year recovery period. Bars are mean \pm S.D. for observed data $(n=65)$ and $95 \%$ confidence intervals $(\mathrm{Cl})$ based on percentiles of 100 simulations. 

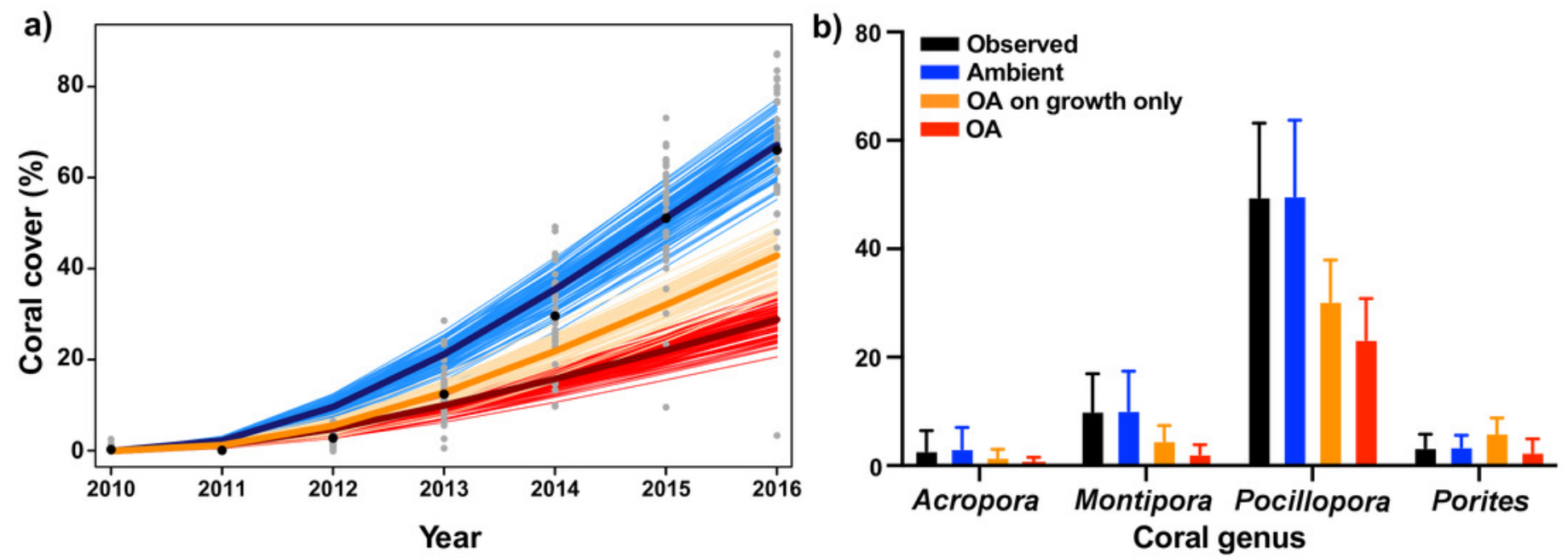
Figure 4

Sensitivity analysis of model simulations to individual changes ( $\pm 20 \%)$ in key parameter values for coral community recovery.

Effects of parameter changes are reflected by percent change from $67 \%$ coral cover after 7 years under ambient conditions.

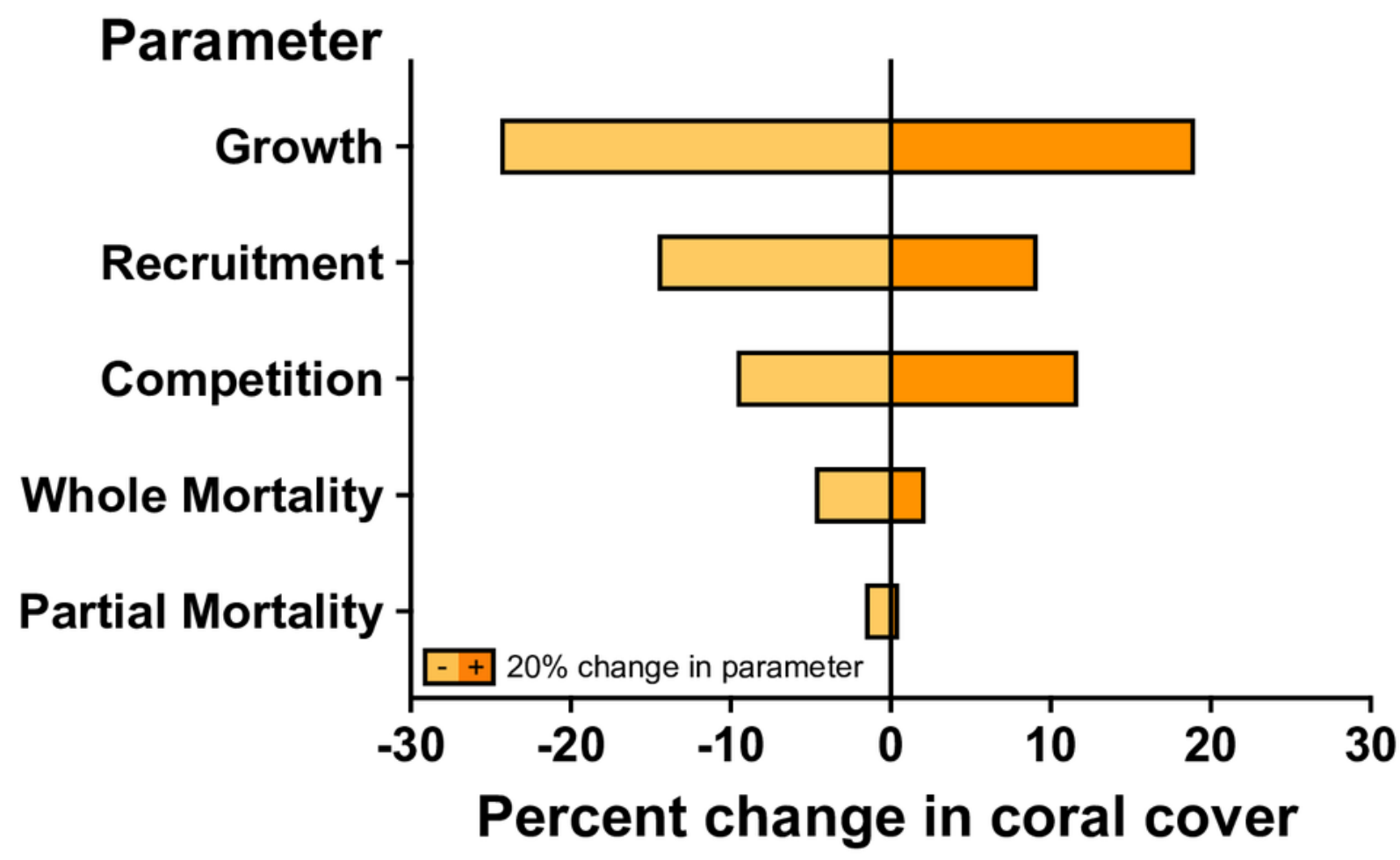

